\title{
Reliabilitystudy of Solar PV Power Production In Terms Of Weather Parameters Using Monte Carlo Simulation
}

\author{
${ }^{*}$ Himani Sharma ${ }^{1}$, Birinchi Bora ${ }^{2}$, Shubham Sharma ${ }^{1}$, Rajesh Kumar ${ }^{2}$, \\ Rashmi Jain ${ }^{1}$ \\ ${ }^{I}$ YMCA University of science and technology, Faridabad, India PIN 121006 \\ ${ }^{2}$ National Institute of Solar Energy, Gurgaon, Ministry of New and Renewable Energy, IndiaPIN 122003 \\ Corresponding Author: Himani Sharma
}

\begin{abstract}
In this study the comprehensive reliability in terms of clearness index for power production of HIT, amorphous silicon \& multi-crystalline silicon $(\mathrm{m}-\mathrm{cSi})$ technologies has been analyzed. The energy estimation of these three technologies is done based on regression, and deviation in the measured and estimated values is also reported. It has been found that for winter season, HIT technology module is the most reliable for overcast and partly cloudy conditions between the HIT, amorphous silicon \&m-cSitechnologies. For summer season, amorphous Silicon technology shows the highest reliability for clear sky condition, m-cSi has the highest reliability for partly cloudy and HIT technology for overcast condition. HIT technology shows higher reliability both in the post monsoon and autumn season for clear sky and partly cloudy index conditions. The error in the estimations has been reduced by increasing the number of iterations.
\end{abstract}

Keyword:Monte Carlo; SPV Module; Environment Parameter; Simulation; Reliability

\section{INTRODUCTION}

The task of demand and supply of power is unachievablein most of the rural part of India. Diverse climatic condition plays a key role in the reduction of energy yield of PV power plant, which brings direct correlation with reliability issue in large power plant [1]. In India, the regions have been mainly divided into 6 climatic zones: Hot and Dry, Warm and Humid, Moderate, Composite, Cold and Cloudy, and Cold and Sunny. The reliability of solar panels is subjected to different weather and environmental conditions depending on the location of their setup. Although the quality of solar cell and module has been quantified in large scale but they degrade over a period of exposure time in outdoor field[2]. Modules defect can occur due to environmental parameters such as high temperature, moisture, heavy rain fall, snow, shading etc. There are four prominent causes for the degradation of a solar cell which have been reported in literature 1) obscuration or absorption in the glass superstrate, 2) obscuration or absorption in the ethylene vinyl acetate (EVA) encapsulant, 3) degradation of the p-n junctions, or 4) thermal degradation. The reliability of the solar module varies with the degradation of the cell and also due to different climatic and weather conditions of each state or location[4]. Two analytical ways were introduced to determine degradation rates from continuous data, the classical decomposition and ARIMA method [5]. The prediction of power output of different PV technologies is also an important subject to study without establishing the plant at various locations with simulation methods. Optimization of the cost of the setup and power generation can be done at maximum level with the help of simulation of power. Previously, many methods have been reported in the literature in order to determine the various specific parameters of the $\mathrm{I}-\mathrm{V}$ characteristics of solar modules. The accuracy of different simulation process needs to be studied for increasing the reliability of estimation. In [6], the uncertainty of power generation from PV modules is studied. An unsymmetrical two point estimate method (U2PEM) has been implemented to handle the uncertainties of the used variables. Monte Carlo Simulation is proposed in [7] to find the reliability of distributed networks and results satisfy that the penetration of distributed generations improves the reliability of the distribution network. Moreover, the reliability factor is also dependent on the operation time and gets decreased when operated for a very long time [8]. In [9], estimation of the maximum power output of photovoltaic (PV) modules with different numbers of parameters including irradiance and PV module temperature as inputs has been used. And results show that under tropical conditions, the one and two parameter models do not give accurate results at low irradiances. Both three and four parameter models are good and give more reasonable results than the 
previous ones. But still they lack in presenting a total model of time span in which the output was actually used because the panel does not generate enough power at low irradiance to make it plausible to be used. In [10], clearness index is considered the best way to predict the sky conditions for operation of solar module.

The aim of this paper is to predict the power output of Amorphous, HIT and Multicrystalline technology based on real time measured data. Monte Carlo Simulation is also used to predict the reliability and interruptions in power production faced by solar PV Modules. The study can expand their use and feasibility of predicting of power outputin which fields it can be used effectively and to what extent by dividing the data according to different seasons and clearness index values. It will help us in describing the ability of a module to function under stated weather conditions of given category for a specified period of time. And can help us easily locate the perfect location for setting up the module of a given technology according to its performance in different climatic conditions of various regions. This study can help the people to choose the suitable PV technology having different types of clearness index distribution.

\section{METHODOLOGY}

For the analysis, the effect of different weather parameters on module power is taken under consideration.These weather parameters are irradiance, ambient temperature, wind speed, wind direction, humidity, clearness index and pressure corrected air mass. The power output by using linear equation is given as

$\mathrm{P}=\mathrm{C}_{1} \mathrm{I}+\mathrm{C}_{2} \mathrm{~T}_{\text {amb }}+\mathrm{C}_{3} \mathrm{~W}_{\mathrm{s}}+\mathrm{C}_{4} \mathrm{~W}_{\text {hum }}+\mathrm{C}_{5} \mathrm{~W}_{\text {dir }}+\mathrm{C}_{6} \mathrm{~K}_{\mathrm{t}}+\mathrm{C}_{7}$ $\mathrm{P}_{\mathrm{am}}+$ Constant $(1)$

$\mathrm{C}_{\mathrm{n}}=$ Regression coefficient, $\mathrm{I}=$ Irradiation on the tilted surface, $\mathrm{T}_{\mathrm{amb}}=$ Ambient temperature, $\mathrm{W}_{\mathrm{s}}=$ Wind speed $\mathrm{W}_{\text {hum }}=$ Humidity, $\mathrm{W}_{\text {dir }}=$ Wind direction, $\mathrm{K}_{\mathrm{t}}=$ Clearness index, $\mathrm{P}_{\mathrm{am}}=$ Pressure corrected Air mass

Air Mass (AM) is calculated using following equation based zenith angle and the atmospheric pressure, model developed by Kastenet al [11]. Already Bora et al has reported about the mostfrequent conditions (MFC)for accurate design of photovoltaic system for the test site based on air mass [12].

$$
A M=\frac{1}{\left\{\operatorname{Cos} \theta_{z}+0.5057\left(96.080-\theta_{z}\right)^{-1.634}\right\}}
$$

$$
A M_{a}=\frac{P}{P_{o}} \cdot A M
$$

Clearness index is defined as the ratio of the global irradiance on a horizontal plane to the extraterrestrial irradiance. It is given by

$k_{t}=\frac{H}{H_{O}}$

Here, $H$ represents the daily global solar radiationand $H_{0}$ representsthe daily extra-terrestrial radiation.

The reliability of the solar module has been defined by the total number of observations for which the power of the module has been obtained in correspondence with irradiance greater than $200 \mathrm{~W} / \mathrm{m}^{2}$. And the error between calculated and measured power is less than $30 \%$. Reliability evaluation also includes the errors and forced interruptions. The interruptions in this case mainly occur due to the low irradiance and other weather parameters like clearness index and temperature. The term for interruption in this study has been named as System Average Interruption Frequency Index (SAIFI). SAIFI defines the number of interruptions (for which the power output of the module was not adequate, i.e. IF (OR (irradiance $<200 \mathrm{~W} / \mathrm{m}^{2}$, error $>30 \%)$ ) to the total number of observations.

And the sum of reliability and SAIFI will be equal to 1.

\section{Or}

Reliability $(\%)+$ SAIFI $(\%)=100 \%$

The data has been divided into 3 categories on the basis of clearness index:

1) Overcast clearness index $(0-0.15)$

2) Partly cloudy clearness index $(0.16-0.60)$

3) Clear sky clearness index(0.61-1)

The clearness index is used as a random variable to run the simulations. For each iteration, the value of clearness index is selected arbitrarily and thus the power equation is also dependent on this random variable. The reliability and SAIFI being dependent on the power equation will also change their values with each iteration. The more the number of iterations, the less will be the error obtained in the calculated power. The data in the fig. 1-fig. 15 show the difference in power output for different seasons and clearness index range. We can find the deviations and the error obtained from the graphs for each technology. The procedure used for the simulation is given in the fig. 16 .

\section{SET-UP}

In order to study the reliability and interruptions in power of different technology PV modules an experimental test-bed facility consisting of three different PV technology module arrays at Gurgaon (Latitude $28.37^{\circ} \mathrm{N}$, Longitude $77.04^{\circ} \mathrm{E}$ ) is considered. The three PV technologies; Amorphous Silicon (a-Si), HIT ( hetro -junction intrinsic thin layer silicon) and Multicrystalline Silicon (m-C- 
Si)modules placed in the real field conditions with fixed rack mount on the aluminum support structure at tilt $28^{\circ}$. The a-Si module array consists of 20 modules with nominal power of $75 \mathrm{Wp}$. The HIT array consists of 10 modules with nominal power of $210 \mathrm{Wp}$. The m-C-Si array consists of 12 modules with nominal power $160 \mathrm{Wp}$. The three PV technology module arrays along with the comprehensive weather monitoring station and PV measurement systems were installed in October 2009. Since then modules in each array are operated at maximum power point except one which is kept in open circuit and current voltage (I-V) data is collected routinely after $10 \mathrm{~min}$ for each technology array. [2]

\section{RESULTS AND DISCUSSION}

The coefficients of the power output equation in Table 2, 3 \& 4 were obtained by applying regression in the tested data and applied in the target data, thus finding the difference between calculated and measured output power for target data.

\subsection{Standard Deviation of error Comparison:}

It can be observed from the table that for winter season, HIT technology has the least standard deviation of error in the overcast index region while the highest for partly cloudy and clear sky index. Multicrystalline Technology has the least value of standard deviation in partly cloudy and clear sky index region.For summer season, HIT technology and Multi-crystalline technology have the least standard deviation for overcast and partly cloudy index respectively. Amorphous technology shows the best results in summer clear sky region showing only a minor standard deviation of error for irradiance greater than $600 \mathrm{~W} / \mathrm{m}^{2}$.For monsoon season, multicrystalline technology gives better results than the other two technologies in the overcast region while HIT technology gives less standard deviation in the partly cloudy region. The error of each technology goes high in the clear sky region in Monsoon season denoting the less possibilities of high clearness index in this season. For post monsoon season, multicrystalline technology gives less standard deviation in overcast region while amorphous technology gives better results for partly cloudy index. The error of each technology goes high in the clear sky region in Post Monsoon season as well denoting the less possibilities of high clearness index in this season. For autumn season, the standard deviation of HIT and Multicrystalline technology are almost equal and much lower thus giving better results than the amorphous technology for partly cloudy and clear sky indices.

\subsection{Average error Comparison:}

While comparing the difference between the calculated and measured power of the module for the winter season, amorphous technology had the highest average error for each index and multicrystalline technology had a minimal rate of average error for each category.In the summer season, amorphous technology module had the least error while multicrystalline technology had the highest value of average error for each clearness index category.In the monsoon season, each technology had very high value of average error in the clear sky region showing less chances of high value of clearness index in this season but for partly cloudy index each technology module had almost equal value of average error.In the post monsoon season, multicrystalline technology gave the least value of average error for each category of clearness index.In the autumn season, HIT technology had the least value of average error for partly cloudy and clear sky index region.

\subsection{Reliability Comparison:}

HIT technology was found to be the most reliable in the winter season for overcast and partly cloudy index while multicrystalline technology is more reliable for clear sky index. The reliability order for summer season varies for each clearness index category showing the highest reliability of amorphous technology for clear sky having irradiance greater than $600 \mathrm{~W} / \mathrm{m}^{2}$. Multicrystalline technology has the highest reliability for partly cloudy index and HIT technology for overcast index region.Multicrystalline technology shows better results than other technologies in the monsoon season for clear sky index region while HIT technology had the highest reliability for the partly cloudy index.HIT technology has a higher reliability both in the post monsoon and autumn season for clear sky and partly cloudy index region.

\subsection{SAIFI Comparison:}

As we know the sum of Reliability and SAIFI must be equal to 1 . Thus higher the reliability, lesser will be the interruption frequency index(SAIFI).Thus, the technologies which have given the highest reliability in any category will have least SAIFI or interruptions in that clearness index or season as shown in the Table 4.

\section{CONCLUSION}

Reliability analysis of a-Si, HIT and m-C-Si PV technology modules for three different clearness index categories is carried out at the real field condition under Indian climatic conditions. Based on the analysis, the main conclusions are as follows:

1) For winter season, HIT technology module is the most reliable for overcast and partly cloudy index. 
2) For summer season, a-Si technology shows the highest reliability for clear sky having irradiance greater than $600 \mathrm{~W} / \mathrm{m}^{2}$. M-C-Si technology has the highest reliability for partly cloudy index and HIT technology for overcast index region.

3) M-C-Si technology can be used in the monsoon season for clear sky index region while HIT technology has the highest reliability for the partly cloudy index.

4) HIT technology gives higher reliability both in the post monsoon and autumn season for clear sky and partly cloudy index region.

\section{ACKNOWLEDGEMENT}

This work was supported by National Institute of Solar Energy, Ministry of New and Renewable Energy, Government of India. The author would like to thank Ms. Supriya, Ms. Rashmi Singh, Mr. Manander and Ms. Renufrom NISE for their input.

\section{REFERENCES}

[1] Bansal N.K. and Minke G., Climatic zones and rural housing in India, Kernforschungsanlage, Juelich, Germany, 1988.

[2] Vikrant Sharma, O.S. Sastry, Arun Kumar, Birinchi Bora, S.S. Chandel. Degradation analysis of a-Si, (HIT) hetro-junction intrinsic thin layer silicon and $\mathrm{m}-\mathrm{C}-\mathrm{Si}$ solar photovoltaic technologies under outdoor Conditions;2014

[3] Ideriah F. J. K. and Suleman S. O. (1989) Sky conditions at Ibadan during 1975-1980. Solar Energy :43, 325-330.

[4] C.R. Osterwald, A. Anderberg, S. Rummel, and L. Ottoson. Degradation Analysis ofWeathered

Crystalline-SiliconPV Modules;2002:7.

[5] Dirk Jordan and Sarah Kurtz. Analytical Improvements in PV Degradation Rate Determination:2010

[6] Soroudi, Alireza; Aien, Morteza; Ehsan, Mehdi. A Probabilistic Modeling of Photo Voltaic Modules and WindPower Generation Impact on Distribution Networks;2011-01.

[7] Ahmed R. Abul'Wafa, A. T. M. Taha. Reliability Evaluation of Distribution Systems under $\mu$ Grid-Tied and Islanded $\mu$ Grid Modes Using Monte Carlo Simulation;2014.

[8] Haiying Wang, Ninghui Zhu, and XiaominBai. Reliability Model Assessment of GridConnected Solar PhotovoltaicSystem Based on MonteCarlo;2015

[9] Kun Ding, Zhen Ye, Thomas Reindl. Comparison of Parameterisation Models for the Estimation of the Maximum Power Output of PV Modules;2011

[10] S. O. UDO. Sky Conditions At Ilorin As Characterized By ClearnessIndex And Relative Sunshine:1999

[11] Kasten, F., and Young, A. T., 1989, "Revised Optical Air Mass Tables and Approximation Formula," Appl. Opt., 28(22), pp. 4735-4738.

[12] Bora B, Sastry OS, Kumar A, Renu, Bangar M, Prasad BB. Estimation of Most Frequent Conditions and Performance Evaluation of Three Photovoltaic Technology Modules. ASME. J. Sol. Energy Eng. 2016;138(5):054504-054504-6. doi:10.1115/1.4034202.

\section{Figure captions List}

Fig 1.Graphs for measured and calculated power for partly cloudy and clear sky index region for a-Si Technology module for winter season.

Fig 2.Graphs for measured and calculated power for partly cloudy and clear sky index region for a-Si Technology module for summer season.

Fig 3.Graphs for measured and calculated power for partly cloudy and clear sky index region for a-Si Technology module for monsoon season.

Fig 4.Graphs for measured and calculated power for partly cloudy and clear sky index region for a-Si Technology module for post monsoon season.

Fig 5.Graphs for measured and calculated power for partly cloudy and clear sky index region for a-Si Technology module for autumn season.

Fig 6.Graphs for measured and calculated power for partly cloudy and clear sky index region for HIT technology module for winter season.

Fig 7.Graphs for measured and calculated power for partly cloudy and clear sky index region for HIT technology module for summer season.

Fig 8.Graphs for measured and calculated power for partly cloudy and clear sky index region for HIT technology module for monsoon season.

Fig 9.Graphs for measured and calculated power for partly cloudy and clear sky index region for HIT technology module for post monsoon season.

Fig 10.Graphs for measured and calculated power for partly cloudy and clear sky index region for HIT technology module for autumn season.

Fig 11.Graphs for measured and calculated power for overcast, partly cloudy and clear sky index region for $\mathrm{m}-\mathrm{C}-\mathrm{Si}$ technology module for winter season.

Fig 12.Graphs for measured and calculated power for overcast, partly cloudy and clear sky index region for $\mathrm{m}-\mathrm{C}-\mathrm{Si}$ technology module for summer season.

Fig 13.Graphs for measured and calculated power for overcast, partly cloudy and clear sky index region for $\mathrm{m}-\mathrm{C}-\mathrm{Si}$ technology module for monsoon season. 
Fig 14.Graphs for measured and calculated power for overcast, partly cloudy and clear sky index region for $\mathrm{m}-\mathrm{C}-\mathrm{Si}$ technology module for post monsoon season.

Fig 15.Graphs for measured and calculated power for overcast, partly cloudy and clear sky index region for $\mathrm{m}-\mathrm{C}-\mathrm{Si}$ technology module for autumn season.

Fig 16.Flow chart of Monte Carlo Simulation.

\section{Table captionList}

Table 1.Voc, Isc, Pmax, Vpm and Ipm corresponding toof a-Si, HIT and m-C-Si technology module

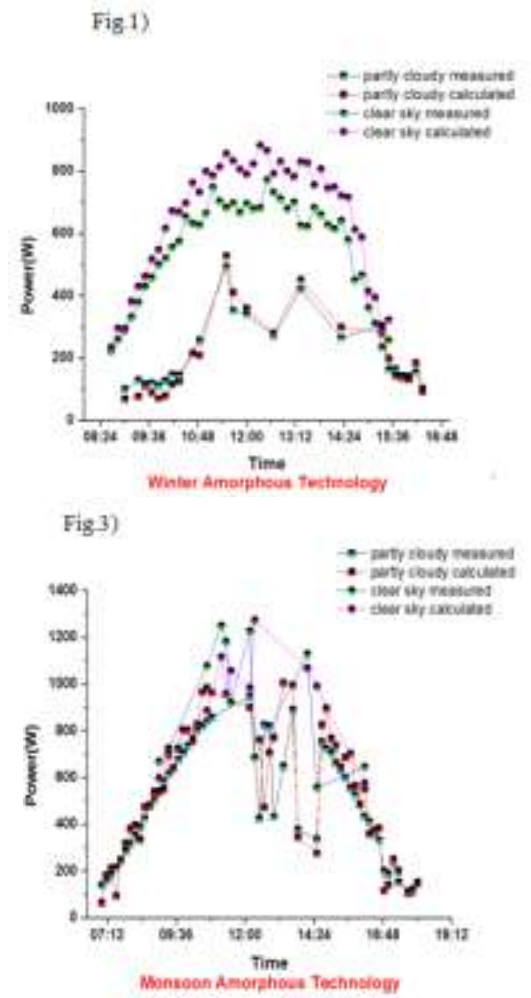

Table 2.Environmental Parameter's Coefficients for m-C-Si Technology.

Table 3.Environmental Parameter's Coefficients for HIT Technology.

Table 4.Environmental Parameter's Coefficients for a-Si Technology

Table 5.Comparison of average error, standard deviation of error, reliability and SAIFI of a-Si, HIT and $\mathrm{m}-\mathrm{C}-\mathrm{Si}$ technology module for winter, summer, monsoon, post monsoon and autumn season for three clearness index categories.

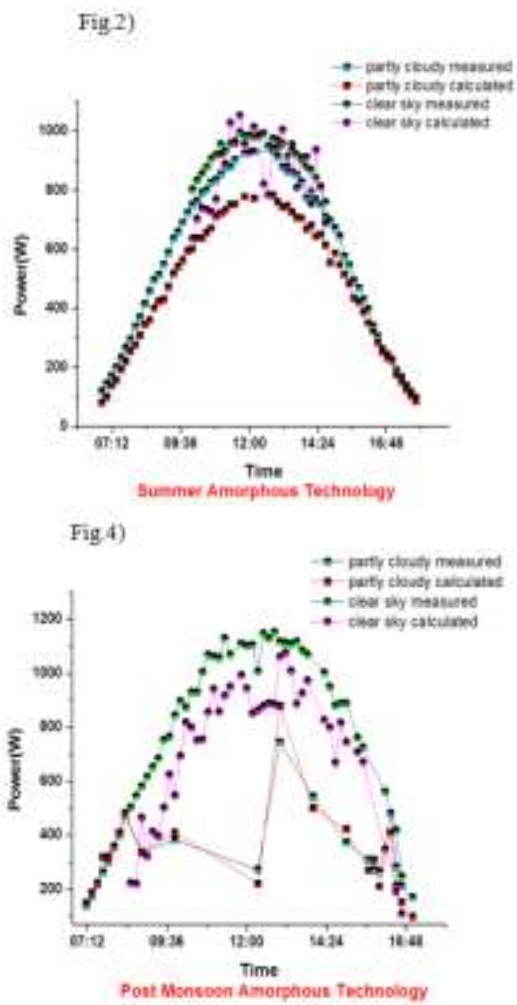

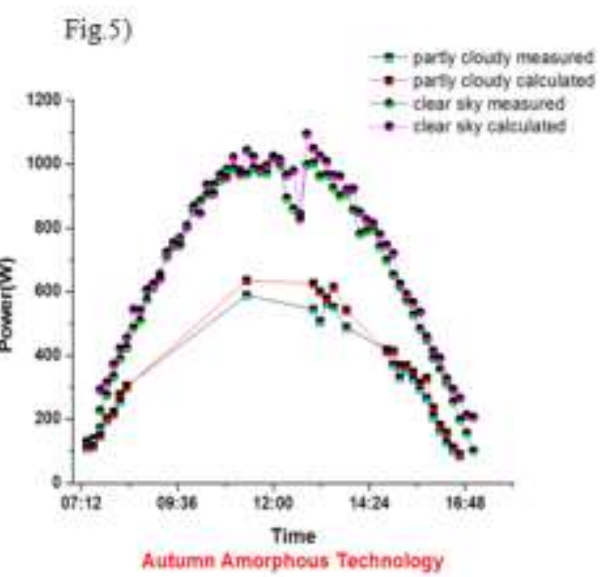



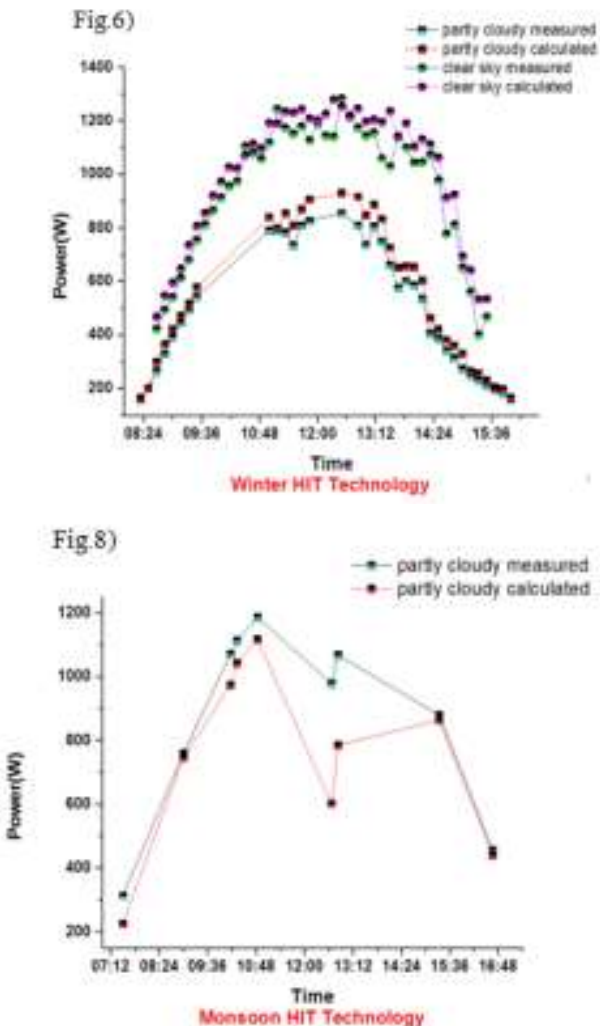
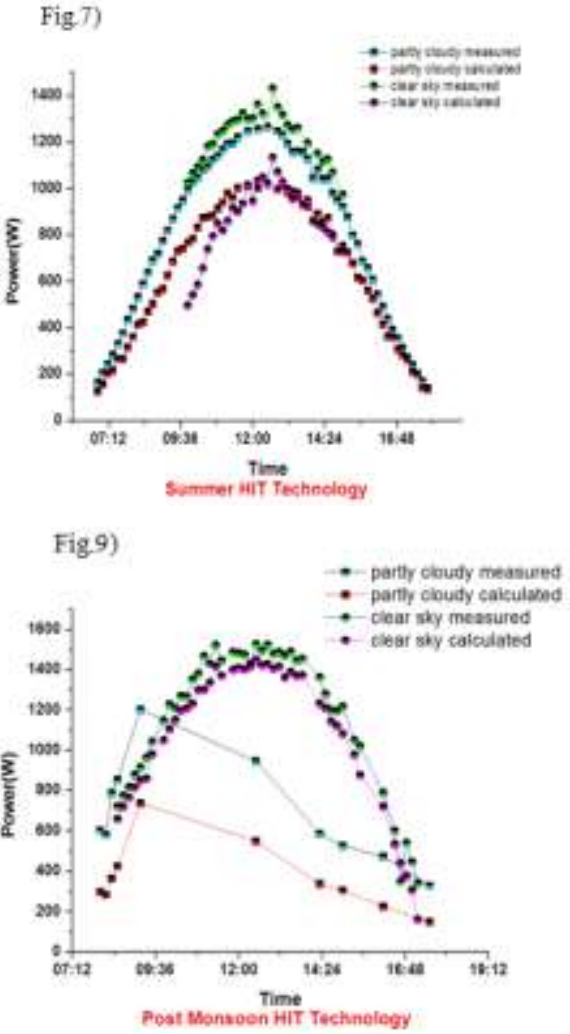
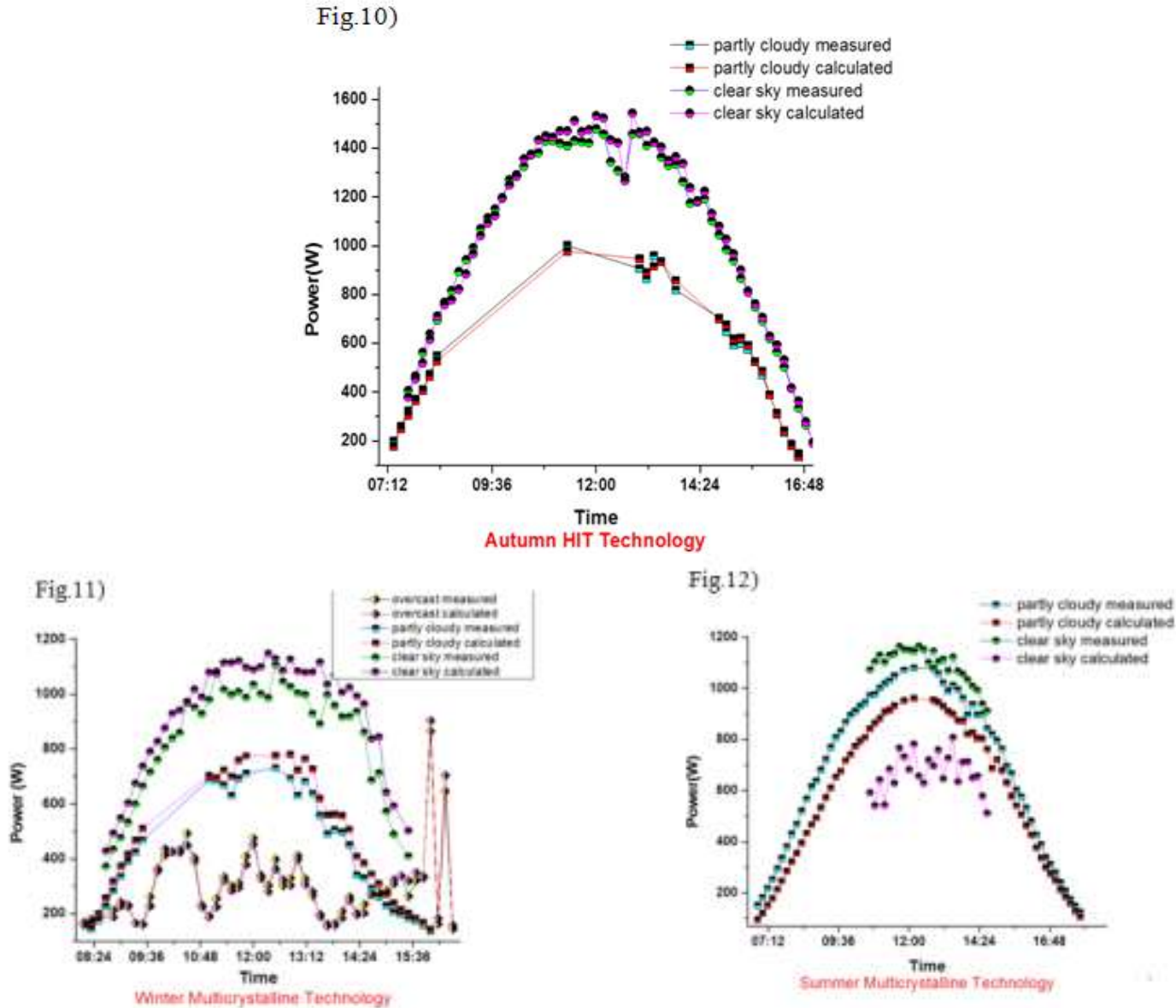

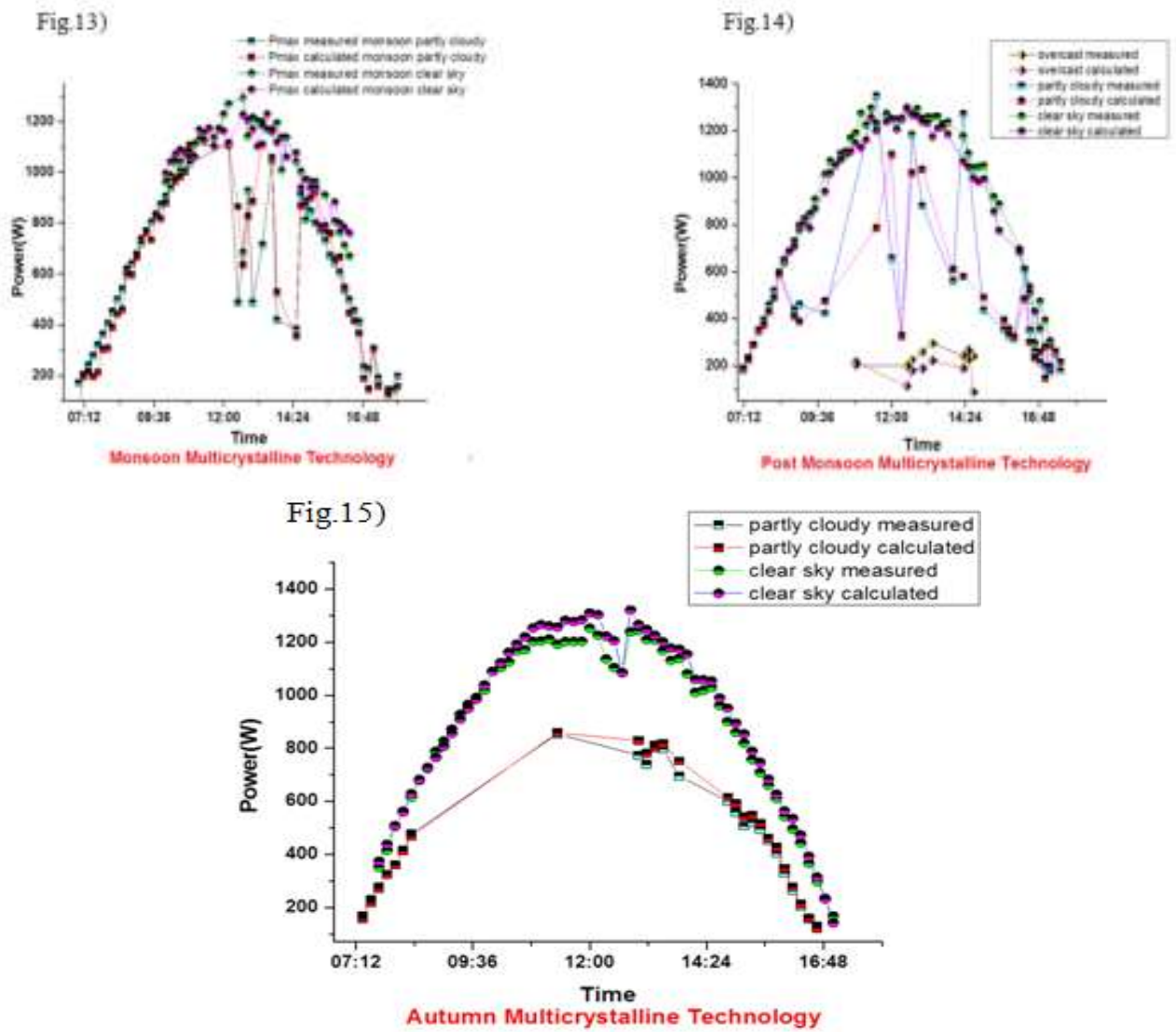

Fig.16)

Segregate the data of tested year into different seasons

Divide the data according to clearness index in three categories:

Overcast clearness index ( 0 to 0.15 ), Partly cloudy clearness index

( 0.16 to 0.60$)$, Clear sky clearness index ( 0.61 to 1$)$

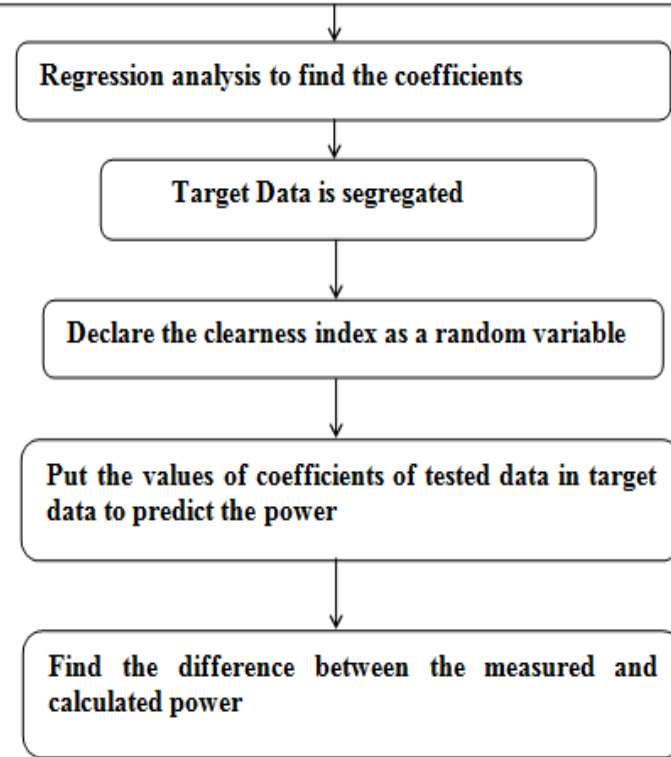




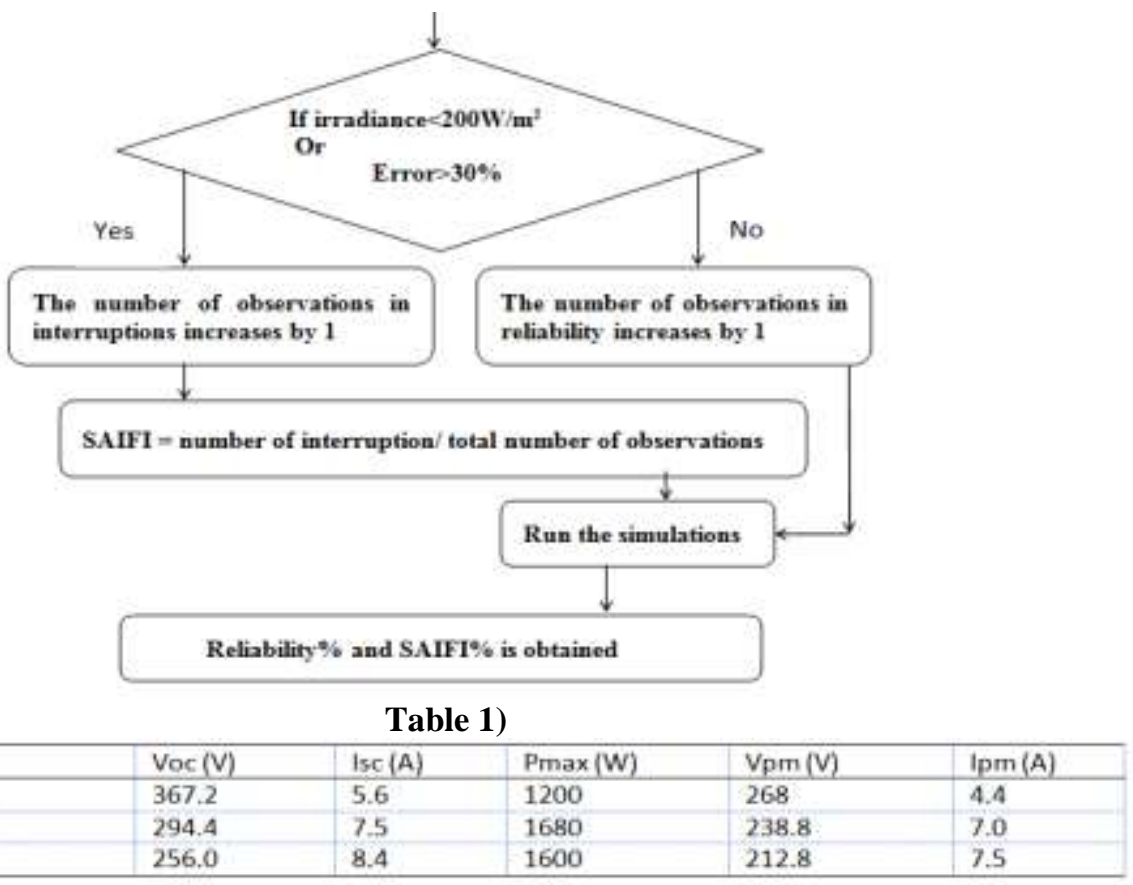

Table 2)

\begin{tabular}{|c|c|c|c|c|c|c|c|c|c|}
\hline Season & Sky conditions & Intercept & $\begin{array}{l}\text { Irradi } \\
\text { ance }\end{array}$ & $\begin{array}{l}\text { Tempera } \\
\text { ture } \\
\text { Average }\end{array}$ & $\begin{array}{l}\text { Humidit } \\
\text { y } \\
\text { Average }\end{array}$ & $\begin{array}{l}\text { Wind } \\
\text { Speed }\end{array}$ & $\begin{array}{l}\text { Wind } \\
\text { Directio } \\
\text { n }\end{array}$ & $\begin{array}{l}\text { Clearness } \\
\text { Index }\end{array}$ & $\begin{array}{l}\text { Pressure } \\
\text { Corrected } \\
\text { AM }\end{array}$ \\
\hline \multirow[t]{3}{*}{ Winter } & Overeast & 266.14 & $\overline{0.295}$ & -1.305 & $=0.48$ & -1.955 & 0.001 & 1505.886 & -122.03 \\
\hline & Partly Cloudy & .53 .758 & 1.574 & 0.414 & 0.625 & 2.782 & -0.029 & -27.565 & 2.489 \\
\hline & Clear Sky & 52.48 & 1.414 & -1.857 & 0.836 & 5.702 & 0.033 & 35.215 & -17.273 \\
\hline \multirow[t]{3}{*}{ Summer } & Overcast & -6.336 & 0.903 & 0.565 & 1.235 & -0.833 & 0.082 & 647,449 & -84.457 \\
\hline & Partly Cloudy & .97 .454 & 1.248 & 1.803 & 0.172 & -1.281 & -0.007 & 9.396 & 1.461 \\
\hline & Clear Sky & -1431.9 & 1.42 & 34.062 & -2.122 & 0.924 & 0.161 & -446.512 & 45,43 \\
\hline \multirow[t]{3}{*}{$\begin{array}{l}\text { Monsoo } \\
\text { D }\end{array}$} & Overcast & 237.86 & 0.266 & -3.462 & 0.531 & -4.128 & 0.045 & 1393.754 & -150.989 \\
\hline & Partly Cloudy & 43.558 & 1.509 & 0.655 & 1.183 & 2.498 & -0.105 & -290.956 & -21.751 \\
\hline & Clear Sky & 499,998 & 0.791 & -5.817 & $-0,316$ & -3.672 & 0.353 & 275.4 & -129.299 \\
\hline \multirow{3}{*}{$\begin{array}{l}\text { Post } \\
\text { Monsoo } \\
\text { D }\end{array}$} & Overcast & 191.13 & 0.556 & -3.217 & 0.408 & -1.929 & -0.022 & 1235.65 & -123.437 \\
\hline & Partly Cloudy & 217.991 & 1.511 & -4.526 & -0.401 & -2.036 & 0.033 & -115.25 & -9.593 \\
\hline & Clear Sky & 1081.94 & 0.979 & -20.515 & -2.459 & 5.121 & 0.14 & 159.566 & -133.129 \\
\hline \multirow[t]{2}{*}{ Autumu } & Partly cloudy & 119.332 & 1.33 & .2 .012 & 0.618 & -3.791 & 0.032 & 11.317 & -23.921 \\
\hline & Clear Sky & 455.494 & 1.29 & -9.877 & $=0.583$ & 4.742 & 0.027 & -11.162 & $-35,971$ \\
\hline
\end{tabular}

Table 3)

\begin{tabular}{|c|c|c|c|c|c|c|c|c|c|}
\hline Season & $\begin{array}{l}\text { Sky } \\
\text { conditions }\end{array}$ & Intercept & $\begin{array}{l}\text { Irradia } \\
\text { nce }\end{array}$ & $\begin{array}{l}\text { Temperature } \\
\text { Average }\end{array}$ & $\begin{array}{l}\text { Humidit } \\
\mathrm{y} \\
\text { Average }\end{array}$ & $\begin{array}{l}\text { Wind } \\
\text { Speed }\end{array}$ & $\begin{array}{l}\text { Wind } \\
\text { Directio } \\
\mathrm{n}\end{array}$ & $\begin{array}{l}\text { Clearness } \\
\text { Index }\end{array}$ & $\begin{array}{l}\text { Pressure } \\
\text { Corrected } \\
\text { AM }\end{array}$ \\
\hline \multirow[t]{3}{*}{ Winter } & Overcast & 93.533 & 1.549 & -1.531 & -0.621 & -2.428 & 0.005 & -9.621 & 0.536 \\
\hline & Partly Cloudy & -43.556 & 1.856 & 0.574 & 0.475 & 1.717 & $-0,030$ & -93.932 & 4.700 \\
\hline & Clear Sky & 77.111 & 1.634 & -3.526 & 0.537 & -1.362 & 0.027 & 27.571 & -13.032 \\
\hline \multirow[t]{3}{*}{ Summer } & Overcast & 274.076 & 1.572 & -6.033 & -0.661 & 3.869 & 0.089 & -526.549 & -19.432 \\
\hline & Partly Cloudy & -95.193 & 1.284 & 1.886 & 0.407 & -2.726 & -0.017 & 94.395 & -6.754 \\
\hline & Clear Sky & -1277.480 & 1.504 & 31.282 & -6.812 & 5.505 & -0.035 & $-183,279$ & 0.756 \\
\hline \multirow[t]{3}{*}{ Monsoon } & Overcast & 238.911 & 0.580 & $-4,088$ & 0.461 & -3.859 & 0,048 & 1206.634 & $-134,742$ \\
\hline & Partly Cloudy & -48.584 & 1.752 & 2.448 & 1.643 & 0.249 & $-0,130$ & -393.407 & -11.690 \\
\hline & Clear Sky & 220.362 & 1.109 & -3.802 & 0.107 & -7.848 & 0.445 & 249.856 & -65.141 \\
\hline \multirow[t]{3}{*}{$\begin{array}{l}\text { Post } \\
\text { Monsoon }\end{array}$} & Overcast & 196.206 & 0.420 & -3.195 & 0.616 & -0.081 & -0.014 & 1604.787 & -152.878 \\
\hline & Partly Cloudy & 28.053 & 1.744 & -2.788 & 0.625 & -0.999 & 0.003 & -77.393 & 2.627 \\
\hline & Clear Sky & 1051.718 & 1.306 & -20.299 & -2.644 & -2.437 & 0.157 & 23.792 & -116.125 \\
\hline \multirow[t]{2}{*}{ Autumn } & Partly cloudy & 133.044 & 1.539 & -2.557 & 0.594 & $-6,247$ & 0.045 & -3.170 & -23.684 \\
\hline & Clear Sky & 496.813 & 1.617 & -11.146 & $=0.908$ & 1.745 & 0.042 & -150.509 & $-20,066$ \\
\hline
\end{tabular}


Table 4)

\begin{tabular}{|c|c|c|c|c|c|c|c|c|c|}
\hline Season & $\begin{array}{l}\text { Sky } \\
\text { conditions }\end{array}$ & Intercept & $\begin{array}{l}\text { Irradian } \\
\text { ce }\end{array}$ & $\begin{array}{l}\text { Temperature } \\
\text { Average }\end{array}$ & $\begin{array}{l}\text { Humid } \\
\text { ity } \\
\text { Averag } \\
\text { e }\end{array}$ & $\begin{array}{l}\text { Wind } \\
\text { Speed }\end{array}$ & $\begin{array}{l}\text { Wind } \\
\text { Directio } \\
\text { n }\end{array}$ & $\begin{array}{l}\text { Clearness } \\
\text { Index }\end{array}$ & $\begin{array}{l}\text { Pressure } \\
\text { Corrected } \\
\text { Am }\end{array}$ \\
\hline \multirow{3}{*}{ Winter } & Overeast & 68.606 & 1.062 & -0.778 & -0.408 & 1.601 & -0.006 & $-46,017$ & -4.392 \\
\hline & Partiy Cloudy & $-131,422$ & 1,399 & 3.619 & 0.875 & 5.361 & -0.018 & -258.337 & 15,407 \\
\hline & Clear Sky & -259.324 & 1.296 & 5.420 & 1.593 & 7.563 & 0.022 & -114.083 & 15.457 \\
\hline \multirow[t]{3}{*}{ Summer } & Overcast & 128.127 & 1.189 & -1.893 & 0.163 & 4.808 & 0.052 & -367568 & -42.191 \\
\hline & Partly Cloudy & -66.077 & 0.975 & 1.416 & 0.196 & -0.288 & -0.006 & 62.944 & -6.687 \\
\hline & $\begin{array}{l}\text { Clear| } \\
\text { Sky(Greater } \\
\text { Than } 600 \\
\left.\text { W/m } / \mathrm{m}^{2}\right)\end{array}$ & 435.832 & 0.861 & -2.420 & 1.528 & 6.428 & -0.014 & 27.461 & -219.526 \\
\hline \multirow[t]{3}{*}{ Monsoon } & Overcast & -60.439 & $-0,601$ & 4.255 & 2.432 & -4.093 & 0.046 & 2158.092 & -216.335 \\
\hline & Partiy Cloudy & $-113,761$ & 1.416 & 3.961 & 1.322 & 2.529 & $-0,087$ & -382.337 & $-2,402$ \\
\hline & Clear Sky & 411.174 & 0,997 & $-7,452$ & -1.664 & 1.075 & 0,323 & -3.465 & -26.337 \\
\hline \multirow[t]{3}{*}{$\begin{array}{l}\text { Post } \\
\text { Monsoon }\end{array}$} & Overcast & 115.552 & 6.704 & -18.030 & -0.878 & 16.564 & -0.034 & 4762.896 & 374.703 \\
\hline & Partly Cloudy & 325.471 & 1.425 & -9.209 & -0.725 & 3.479 & -0.007 & -152.621 & 2.460 \\
\hline & Clear Sky & 1356.985 & 0.994 & -15.133 & -6.003 & -7.732 & 0.311 & -598.364 & -107.271 \\
\hline \multirow[t]{2}{*}{ Autumn } & Partiy Cloudy & -19.856 & 1.050 & 1.962 & 0.964 & 0.121 & $=0.005$ & -147.722 & -7.729 \\
\hline & Clear Sky & -251.620 & 1.151 & 0.681 & 0.817 & 0.619 & -0.003 & 200.146 & 9.992 \\
\hline
\end{tabular}

Table 5)

\begin{tabular}{|c|c|c|c|c|c|c|c|c|c|c|c|c|c|}
\hline \multirow[t]{2}{*}{ Seasont } & \multirow{2}{*}{$\begin{array}{l}\text { Sky } \\
\text { conditions }\end{array}$} & \multicolumn{3}{|c|}{ Average error } & \multicolumn{3}{|c|}{$\begin{array}{l}\text { Standard deviation of } \\
\text { error }\end{array}$} & \multicolumn{3}{|c|}{ Reliability } & \multicolumn{3}{|l|}{ Saifi } \\
\hline & & $\begin{array}{l}\text { Amor } \\
\text { phous }\end{array}$ & HII & $\begin{array}{l}\text { Multi } \\
\text { erysta } \\
\text { Iline }\end{array}$ & $\begin{array}{l}\text { Amor } \\
\text { phous }\end{array}$ & HIT & $\begin{array}{l}\text { Multi } \\
\text { crysta } \\
\text { lline }\end{array}$ & $\begin{array}{l}\text { Amor } \\
\text { phous }\end{array}$ & HII & $\begin{array}{l}\text { Multi } \\
\text { crysta } \\
\text { lline }\end{array}$ & $\begin{array}{l}\text { Amot } \\
\text { phous }\end{array}$ & HIT & $\begin{array}{l}\text { Multi } \\
\text { crysta } \\
\text { lline }\end{array}$ \\
\hline \multirow[t]{3}{*}{ Winter } & overcast & 10,58 & 9.91 & & 12.07 & 8.47 & & 2.94 & 58.82 & & 97.05 & 41.17 & \\
\hline & partly cloudy & 20.67 & 14.19 & 11.69 & 14.43 & 16.13 & 8.47 & 42.48 & 78.19 & 71.19 & 57.52 & 21.80 & 28.69 \\
\hline & clear sky & 12.51 & 6.56 & 7.64 & 6.46 & 10.09 & 5.95 & 92.91 & 97.79 & 98.55 & 7.06 & 2.25 & 1.35 \\
\hline \multirow{4}{*}{ Summer } & overcast & 14.06 & 14.68 & 25.39 & 14.50 & 10.32 & 16.95 & 26.98 & 58.73 & 31.47 & 71.42 & 41.27 & 68.25 \\
\hline & partly cloudy & 16.41 & 20.62 & 16.61 & 14.66 & 10.46 & 8.16 & 73.95 & 81.89 & 88.10 & 26.33 & 18.19 & 11.89 \\
\hline & $\begin{array}{l}\text { clear sky } \\
\text { (irradiance } \\
>600 \mathrm{~W} / \mathrm{m}^{2} \text { ) }\end{array}$ & 5,88 & & 36.28 & 3.67 & & 11.38 & 100.0 & & \multirow[t]{2}{*}{32.64} & & & 67.35 \\
\hline & $\begin{array}{l}\text { clear sky } \\
\text { (irradiance } \\
<-600 \mathrm{~W} / \mathrm{m}^{2} \text { ) }\end{array}$ & 18.89 & & & 31.94 & & & 85.61 & & & 14.38 & & \\
\hline \multirow[t]{2}{*}{ Monsoon } & partly cloudy & 17.55 & 15.16 & 15.92 & 16.94 & 15.5 & 17.20 & 13.32 & 85 & 81.53 & 86.91 & 15 & 18.46 \\
\hline & clear sky & 15.56 & & 18.29 & 29.85 & & 35.28 & 45.45 & & 87.92 & 54.54 & & 12.07 \\
\hline \multirow{2}{*}{$\begin{array}{l}\text { Post } \\
\text { Monsoon }\end{array}$} & partly cloudy & 12.95 & & 14.89 & 12.90 & & 19.85 & 78.72 & & 76.42 & 21.04 & & 23.58 \\
\hline & clear sky & 22.51 & 33.9 & 13.63 & 31.99 & 33,9 & 34.3 & 79.40 & 93.41 & 93.87 & 20.22 & 33.8 & 6.12 \\
\hline \multirow[t]{2}{*}{ Autumn } & partly cloudy & 16,80 & 5.99 & 7.73 & 11.93 & 7.17 & 7.97 & 51.27 & 85.10 & 79.36 & 48.51 & 14.89 & 20.63 \\
\hline & clear sky & 13.43 & 4.91 & 6.75 & 13.86 & 8.61 & 8.63 & 93.63 & 98.69 & 98.61 & 6.20 & 1.38 & 1.38 \\
\hline
\end{tabular}

International Journal of Engineering Research and Applications (IJERA) is UGC approved Journal with Sl. No. 4525, Journal no. 47088. Indexed in Cross Ref, Index Copernicus (ICV 80.82), NASA, Ads, Researcher Id Thomson Reuters, DOAJ.

Himani Sharma. "Reliabilitystudy of Solar PV Power Production In Terms Of Weather Parameters Using Monte Carlo Simulation." International Journal of Engineering Research and Applications (IJERA) 7.7 (2017): 37-45. 